\title{
Molecular Detection of Antimalarial Drug Resistance in Plasmodium vivax from Returned Travellers to NSW, Australia during 2008-2018
}

\author{
Chaturong Noisang ${ }^{1,2}$, Wieland Meyer ${ }^{1,2,3} \mathbb{D}$, Nongyao Sawangjaroen ${ }^{4}$, John Ellis ${ }^{5}(\mathbb{D}$ \\ and Rogan Lee ${ }^{6, *(\mathbb{D})}$ \\ 1 Marie Bashir Institute for Infectious Diseases and Biosecurity, The University of Sydney, \\ Sydney, NSW 2006, Australia; chaturongmt@gmail.com (C.N.); wieland.meyer@sydney.edu.au (W.M.) \\ 2 Westmead Institute for Medical Research, Westmead, NSW 2145, Australia \\ 3 Westmead Hospital (Research and Education Network), Westmead, NSW 2145, Australia \\ 4 Department of Microbiology, Faculty of Science, Prince of Songkla University, Hat Yai, \\ Songkhla 90110, Thailand; nongyao.s@psu.ac.th \\ 5 School of Life Sciences, University of Technology Sydney, Ultimo, NSW 2007, Australia; \\ John.Ellis@uts.edu.au \\ 6 Centre for Infectious Diseases and Microbiology Laboratory Services, NSW Health Pathology-ICPMR, \\ Westmead Hospital, Westmead, NSW 2145, Australia \\ * Correspondence: rogan.lee@health.nsw.gov.au; Tel.: +61-2-88906255
}

Received: 23 October 2019; Accepted: 3 February 2020; Published: 5 February 2020

\begin{abstract}
To monitor drug resistance in Plasmodium vivax, a multidrug resistance 1 (Pvmdr1) gene and a putative transporter protein (Pvcrt-o) gene were used as molecular markers for chloroquine resistance. The biomarkers, the dihydrofolate reductase (Pvdhfr) gene and the dihydropteroate synthetase (Pvdhps) gene, were also used for the detection of resistance to sulphadoxine-pyrimethamine (SP); this drug is often accidentally used to treat $P$. vivax infections. Clinical blood samples $(n=120)$ were collected from patients who had been to one of eight malaria-endemic countries and diagnosed with $P$. vivax infection. The chloroquine resistance marker, the Pvmdr1 gene, showed F976:L1076 mutations and L1076 mutation. A K10 insertion in the Pvcrt-o gene was also found among the samples successfully sequenced. A combination of L/I57:R58:M61:T117 mutations in the Pvdhfr gene and G383:G553 mutations in the Pvdhps gene were also observed. Mutations found in these genes indicate that drug resistance is present in these eight countries. Whether or not countries are using chloroquine to treat $P$. vivax, there appears to be an increase in mutation numbers in resistance gene markers. The detected changes in mutation rates of these genes do suggest that there is still a trend towards increasing P. vivax resistance to chloroquine. The presence of the mutations associated with SP resistance indicates that $P$. vivax has had exposure to SP and this may be a consequence of either misdiagnosis or coinfections with P. falciparum in the past.
\end{abstract}

Keywords: plasmodium vivax; drug resistance; chloroquine; sulfadoxine-pyrimethamine

\section{Introduction}

In Australia, about 500 malaria cases are reported each year [1] and just under half of them are diagnosed with Plasmodium vivax [2]. All cases are in travellers who have been to malaria-endemic countries. Plasmodium falciparum remains the predominant malaria species, but $P$. vivax has become the major cause of human malaria in endemic regions outside of Africa, such as Asia, Central and South America and Oceania. Globally, it is estimated that there are between 80 million and up to 400 million vivax malaria cases each year [3-5]. Although malaria control and elimination programs are promoted 
in these countries, these programs are being hindered by the emergence of drug-resistant strains of P. vivax.

Usually, chloroquine-sensitive strains of $P$ vivax are cleared from the blood within $48 \mathrm{~h}$ after a patient receives a standard dose of $25 \mathrm{mg} / \mathrm{kg}$ chloroquine [6]. However, chloroquine-resistant strains can recrudesce within 14 days after the start of treatment. A recurrent parasitemia with $100 \mathrm{ng} / \mathrm{mL}$ of the measured chloroquine concentration in whole blood on or before the 28th day of treatment is classified as resistant $[3,6]$. Chloroquine resistance in P. vivax was found around the late 1980s and resistance was first reported in Australian travellers, who were diagnosed with $P$. vivax infection after returning from Papua New Guinea (PNG) $[7,8]$. These travellers failed to clear the parasitemia by the standard chloroquine dose $[3,6,9,10]$. During this period, other reports of chloroquine-resistant P. vivax arose from Asian and South American countries [9].

For P. falciparum, the chloroquine-resistant phenotype is strongly associated with mutations in a P. falciparum chloroquine resistance transporter ( $P f c r t)$ gene and a P. falciparum multidrug-resistant transporter-1 (Pfmdr1) gene. Studies demonstrated that the Pfcrt gene encodes a transmembrane protein located on the parasite digestive vacuole [11,12]. A strain of $P$. falciparum with a mutation of the gene $P f c r t$ alters the movement of CQ away from heme into the parasite digestive vacuole. As a result, the parasite survives under therapeutic CQ levels $[12,13]$. Unlike P. falciparum, chloroquine-resistant $P$. vivax has been extremely difficult to investigate due to the characteristics of this parasite, which include the presence of dormant forms in the liver, some cases with very low parasitaemia, no effective long-term in vitro assay, and the inability to distinguish between relapse, recrudescence and reinfection in therapeutic efficacy studies $[14,15]$. Therefore, the mechanisms of CQ resistance in P. vivax remain unclear. However, studies found correlations between chloroquine-resistant $P$. vivax phenotype and mutations in the multidrug resistance 1 (Pvmdr1) gene, and the putative transporter protein (Pvcrt-o) gene. These genes are orthologous to Pfmdr1 and Pfcrt genes in P. falciparum [3,16-18]. The Pvmdr1 gene is located on chromosome 10, containing 24 single nucleotide polymorphisms (SNPs), while the Pvcrt-o gene is located on chromosome 1, contains 5 SNPs and a lysine insertion at the amino acid position 10 [19]. Although molecular methods may not be the most effective tool to monitor drug resistance in $P$. vivax, well-characterised molecular biomarkers do allow for retrospective studies to be done so that molecular changes can be monitored. The multidrug resistance 1 (Pvmdr1) gene and the putative transporter protein (Pvcrt-o) gene are the recommended markers to monitor chloroquine resistance in P. vivax.

Sulfadoxine-pyrimethamine (SP) combined with other drugs was widely used in the past [20] and remains in use in a few countries such as Iran, Saudi Arabia, Yemen and India to treat patients with uncomplicated P. falciparum infections [21]. However, P. vivax can be exposed to SP either as a coinfection with P. falciparum or following a misdiagnosis of malaria species. Furthermore, SP was suggested as an alternative treatment for vivax malaria in some areas [22], specifically those locations with high rates of mixed infections [23]. Reports have shown that genetic-resistant strains of P. vivax to SP treatment can be identified by the detection of mutations present in the dihydrofolate reductase (Pvdhfr) and dihydropteroate synthetase (Pvdhps) genes [24]. Pyrimethamine resistance correlates with specific single nucleotide polymorphisms of the Pvdhfr gene, which results in decreased enzyme affinity to pyrimethamine $[24,25]$, whereas sulfadoxine resistance is associated with nucleotide polymorphisms within the Pvdhps gene [24]. This study aimed to detect the prevalence of molecular resistance markers for chloroquine, sulfadoxine and pyrimethamine in P. vivax-infected travellers returning to NSW, Australia.

\section{Results}

All P. vivax isolates came from infected travellers returning to Australia from India, PNG, Pakistan, Indonesia, Thailand, Solomon Islands, South Korea and Cambodia. Analyses for the presence of resistance biomarkers were undertaken based on geographical region, as numbers from individual countries were low and some would be poorly represented in this survey (see Table S1). The majority 
of our patients were male (89/120) and most were in the 21-30 years age group (27/88) (see Table 1). Only 23 females were present in this study with most in the 21-30 and over 61 years age groups. Nine samples had no gender recorded.

Table 1. Demographics of patients included in this study.

\begin{tabular}{ccccccccc}
\hline Gender & $\mathbf{1 0}$ & $\mathbf{1 1 - 2 0}$ & $\mathbf{2 1 - 3 0}$ & $\mathbf{3 1 - 4 0}$ & $\mathbf{4 1 - 5 0}$ & $\mathbf{5 1 - 6 0}$ & $\mathbf{6 1} \leq$ & Total Number \\
\hline Male & 1 & 9 & 27 & 17 & 7 & 12 & 15 & 88 \\
Female & 2 & 0 & 7 & 1 & 1 & 5 & 7 & 23 \\
Unknown & 0 & 0 & 2 & 0 & 1 & 1 & 5 & 9 \\
\hline
\end{tabular}

2.1. Sequence Analysis of The Multidrug Resistance 1 (Pvmdr1) Gene, and The Putative Transporter Protein (Pvort-o) Gene

Pvmdr1 amplicons ( $\mathrm{n}=109)$ were successfully sequenced and displayed mutations at codon 976 and 1076. As shown in Table 2, double F976:L1076 mutations were observed in all regions: Oceania (23/37), Southeast Asia (5/10) and South Asia (2/73). In Oceania, PNG showed the highest prevalence of mutations, with 22/29 of isolates (see Table S2). The single L1076 mutation was also detected in all three regions: South Asia (50/73), Oceania (8/37) and Southeast Asia (5/10). This mutation showed the highest prevalence in India (36/51) and Pakistan (14/17) (see Table S2). All single F976 mutations were found in India (7/51) (see Table S2) and nine isolates from the South Asia region were identified as wildtype.

Table 2. Prevalence of target mutations in the multidrug resistance 1 (Pvmdr1) gene and the putative transporter protein (Pvcrt-o) gene, amongst return travellers to NSW, Australia during 2008-2018.

\begin{tabular}{|c|c|c|c|c|c|}
\hline \multirow[b]{2}{*}{ Genotype } & \multirow[b]{2}{*}{ Mutations } & \multicolumn{3}{|c|}{ Regions } & \multirow{2}{*}{$\begin{array}{c}\text { Total } \\
(\mathrm{N}=120)\end{array}$} \\
\hline & & $\begin{array}{c}\text { SA } \\
\mathrm{n}=73\end{array}$ & $\begin{array}{c}\text { SEA } \\
\mathrm{n}=\mathbf{1 0}\end{array}$ & $\begin{array}{c}\text { Oceania } \\
n=37\end{array}$ & \\
\hline \multicolumn{6}{|l|}{ Pvmdr1 } \\
\hline & $\begin{array}{c}\text { Wildtype } \\
\text { Y976:F1076 }\end{array}$ & $9(12 \%)$ & 0 & 0 & $9(7.5 \%)$ \\
\hline & $\begin{array}{l}\text { Single Mutation } \\
\text { F976 }\end{array}$ & $7(9.5 \%)$ & 0 & 0 & $7(5.8 \%)$ \\
\hline & $\begin{array}{l}\text { Single Mutation } \\
\text { L1076 }\end{array}$ & $50(68 \%)$ & $5(50 \%)$ & $8(21.6 \%)$ & $63(52.5 \%)$ \\
\hline & $\begin{array}{c}\text { Double Mutations } \\
\text { F976:L1076 }\end{array}$ & $2(2.5 \%)$ & $5(50 \%)$ & $23(62 \%)$ & $30(25 \%)$ \\
\hline \multicolumn{6}{|l|}{ Pvcrt-o } \\
\hline & Wildtype & $49(67 \%)$ & $6(60 \%)$ & $22(59 \%)$ & $77(64 \%)$ \\
\hline & $\underline{\text { K}} 10$ Insertion & $9(12 \%)$ & $2(20 \%)$ & 0 & $11(9 \%)$ \\
\hline
\end{tabular}

South Asia (SA): India and Pakistan; Southeast Asia (SEA): Indonesia, Thailand, Cambodia plus South Korea (includes one case with exposure to multiple countries of SEA (SEAN)); Oceania: Papua New Guinea and Solomon Islands.

A K10 insertion in the Pvcrt-o gene was identified in nine isolates from India (South Asia) and two isolates from Southeast Asia. No other isolate from this study group had this insertion (see Table 2).

\subsection{Sequence Analysis of The Dihydrofolate Reductase (Pvdhfr) Gene}

A total of 112 sequences were amplified using primers targeting the Pvdhfr gene. The majority of the isolates expressing the wildtype genotype were from South Asia (43/53), while a few were present in Oceania (7/37) and Southeast Asia (3/10) (see Table 3). Mutations were observed at codons 57, 58, 61,

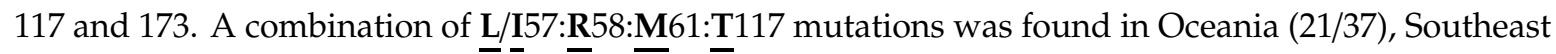


Asia (4/10) and South Asia (2/73) (see Table 3). In Oceania, many isolates (19/33) from PNG carried these mutations (see Table S2). Two mutations at R58:N117 were detected in the three regions South Asia (18/73), Southeast Asia (2/10) and Oceania (1/37). Amongst the South Asian isolates, India (13/50) and Pakistan (5/17) had similar proportions of the R58:N117 mutations (see Table S2). The other two mutations at L57:R58 were observed in Oceania (5/37) and South Asia (1/73) in low numbers and the single mutation at $\mathbf{N} 117$ was also found in a few samples from South Asia (3/73), Oceania (1/37) and Southeast Asia (1/10).

Table 3. Prevalence of SP resistant-associated genotypes in the dihydrofolate reductase (Pvdhfr) gene and the dihydropteroate synthetase (Pvdhps) gene, amongst return travellers to NSW, Australia during 2008-2018.

\begin{tabular}{|c|c|c|c|c|c|}
\hline \multirow[b]{2}{*}{ Genotype } & \multirow[b]{2}{*}{ Mutations } & \multicolumn{3}{|c|}{ Regions } & \multirow[b]{2}{*}{$\begin{array}{c}\text { Total } \\
(\mathrm{N}=120)\end{array}$} \\
\hline & & $\begin{array}{c}\text { SA } \\
\mathbf{n}=73\end{array}$ & $\begin{array}{c}\text { SEA } \\
\mathrm{n}=10\end{array}$ & $\begin{array}{c}\text { Oceania } \\
\mathbf{n}=37\end{array}$ & \\
\hline \multicolumn{6}{|l|}{ Pvdhfr } \\
\hline & $\begin{array}{c}\text { Wildtype } \\
\text { F57:S58:T61:S117:I173 }\end{array}$ & $\begin{array}{c}43 \\
(59 \%)\end{array}$ & $\begin{array}{c}3 \\
(30 \%)\end{array}$ & $\begin{array}{c}7 \\
(19 \%)\end{array}$ & $\begin{array}{c}53 \\
(44 \%)\end{array}$ \\
\hline & $\begin{array}{l}\text { Single Mutation } \\
\text { N117 }\end{array}$ & $\begin{array}{c}3 \\
(4 \%)\end{array}$ & $\begin{array}{c}1 \\
(10 \%)\end{array}$ & $\begin{array}{c}1 \\
(10 \%)\end{array}$ & $\begin{array}{c}5 \\
(4 \%)\end{array}$ \\
\hline & $\begin{array}{l}\text { Double Mutations } \\
\text { ㄷ5:스117 }\end{array}$ & $\begin{array}{c}18 \\
(24.5 \%)\end{array}$ & $\begin{array}{c}2 \\
(20 \%)\end{array}$ & $\begin{array}{c}1 \\
(2.7 \%)\end{array}$ & $\begin{array}{c}21 \\
(17.5 \%)\end{array}$ \\
\hline & $\begin{array}{l}\text { Double Mutations } \\
\text { L57:ㅈ5 }\end{array}$ & $\begin{array}{c}1 \\
(1 \%)\end{array}$ & 0 & $\begin{array}{c}5 \\
(13.5 \%)\end{array}$ & $\begin{array}{c}6 \\
(5 \%)\end{array}$ \\
\hline & 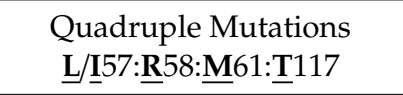 & $\begin{array}{c}2 \\
(2.5 \%) \\
\end{array}$ & $\begin{array}{c}4 \\
(40 \%)\end{array}$ & $\begin{array}{c}21 \\
(56.7 \%)\end{array}$ & $\begin{array}{c}27 \\
(22.5 \%)\end{array}$ \\
\hline \multicolumn{6}{|l|}{ Pvdhps } \\
\hline & $\begin{array}{c}\text { Wildtype } \\
\text { S382:A383:K512:A553:V585 }\end{array}$ & $\begin{array}{c}62 \\
(84.9 \%)\end{array}$ & $\begin{array}{c}5 \\
(50 \%)\end{array}$ & $\begin{array}{c}35 \\
(94.5 \%)\end{array}$ & $\begin{array}{c}102 \\
(85 \%)\end{array}$ \\
\hline & $\begin{array}{l}\text { Single Mutation } \\
\text { G383 }\end{array}$ & $\begin{array}{c}2 \\
(2.7 \%)\end{array}$ & $\begin{array}{c}1 \\
(10 \%)\end{array}$ & 0 & $\begin{array}{c}3 \\
(2.5 \%)\end{array}$ \\
\hline & $\begin{array}{l}\text { Single Mutation } \\
\text { G553 }\end{array}$ & $\begin{array}{c}1 \\
(1 \%)\end{array}$ & $\begin{array}{c}1 \\
(10 \%)\end{array}$ & 0 & $\begin{array}{c}2 \\
(1.6 \%)\end{array}$ \\
\hline & $\begin{array}{l}\text { Double Mutations } \\
\text { G383:G553 }\end{array}$ & $\begin{array}{c}6 \\
(8 \%)\end{array}$ & $\begin{array}{c}2 \\
(20 \%)\end{array}$ & $\begin{array}{c}1 \\
(2.7 \%)\end{array}$ & $\begin{array}{c}9 \\
(7.5 \%)\end{array}$ \\
\hline
\end{tabular}

South Asia (SA): India and Pakistan; Southeast Asia (SEA): Indonesia, Thailand, Cambodia plus South Korea (includes one case with exposure to multiple countries of SEA (SEAN)); Oceania: Papua New Guinea and Solomon Islands.

\subsection{Sequence Analysis of The Dihydropteroate Synthetase (Pvdhps) Gene}

Amplicons $(n=116)$ that were successfully sequenced had mutations at codons $382,383,512$, 553 and 585. The wildtype genotype was found in all three regions, the majority of which were in South Asia (62/73), Oceania (35/37) and small numbers in Southeast Asia (5/10). Two mutations at G383:G553 loci were found in South Asia (6/73) (all six came from India), Southeast Asia (2/10) and Oceania (1/37). Isolates showing the single G383 mutation were identified in South Asia (2/73) and Southeast Asia (1/10). The single G553 mutation was only found in one isolate from South Asia and one from Southeast Asia.

\subsection{The Prevalence of Tandem Repeat Variants in the Dihydrofolate Reductase (Pvdhfr) Gene}

Tandem repeat variants found in the Pvdhfr gene locus have been described by different laboratories [26]; the typing of these variants in this study followed that of a recent Thai study from 2018 [7]. This group described three different tandem repeat variants found in the Pvdhfr gene 
sequence. The reference strain (Accession No. X98123.1) [27] contains three repeat sets of four amino acids ( $5^{\prime}$-GGDN-3') between codons 88 and 103 and was designated as Type 1 or wildtype. The tandem repeat sequence that lacks the six amino acid at codons 98-103 was designated as Type 2. Type 3 sequences have an additional six amino acids inserted between codons 103 and 104.

Type 1 (wildtype) was the predominant sequence found in all regions (see Table 4). Isolates showing Type 1 sequences were from India (44/51), PNG (16/33), Pakistan (11/17) and Indonesia (4/5). A few isolates had Type 2 repeat variants found in South Asia (9/68) and Southeast Asia (3/10). Type 3 tandem repeats were found mainly in isolates from PNG (17/33) and a few isolates from South Asia $(4 / 68)$ and Southeast Asia (1/10).

Table 4. The prevalence of tandem repeat variants in the dihydrofolate reductase (Pvdhfr) gene.

\begin{tabular}{cccc}
\hline Countries & Type 1 & $\begin{array}{c}\text { Pvdhfr gene } \\
\text { Type 2 }\end{array}$ & Type 3 \\
\hline $\begin{array}{c}\text { SA } \\
(\mathbf{n}=73)\end{array}$ & $55(75 \%)$ & $9(12 \%)$ & $4(5 \%)$ \\
$\begin{array}{c}\text { SEA } \\
(\mathbf{n}=\mathbf{1 0})\end{array}$ & $6(60 \%)$ & $3(30 \%)$ & $1(10 \%)$ \\
$\begin{array}{c}\text { Oceania } \\
(\mathbf{n}=\mathbf{3 7})\end{array}$ & $16(43 \%)$ & - & $19(51 \%)$ \\
$\begin{array}{c}\text { Total } \\
(\mathbf{N}=\mathbf{1 2 0})\end{array}$ & $77(64 \%)$ & $12(10 \%)$ & $24(20 \%)$ \\
\hline
\end{tabular}

South Asia (SA): India and Pakistan; Southeast Asia (SEA): Indonesia, Thailand, Cambodia plus South Korea (includes one case with exposure to multiple countries of SEA (SEAN)); Oceania: Papua New Guinea and Solomon Islands.

\section{Discussion}

About 30 years ago, the first chloroquine resistance in P. vivax was found [8] and subsequently, it appeared in several other countries such as the Solomon Islands, Indonesia, Malaysia, Thailand, Ethiopia, Brazil and Peru [15]. Molecular markers of chloroquine resistance in P. vivax, Pvmdr1 and Pvcrt-o genes were used as they are orthologous to Pfmdr1 and Pfcrt genes, which are associated with chloroquine resistance in P. falciparum [6]. Among the studied samples herein, the presence of the F976 and L1076 mutations in the Pvmdr1 gene and the K10 insertion in the Pvcrt-o gene were shown

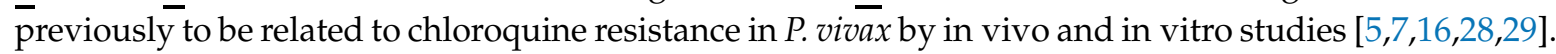

This study obtained sequences from both Pvmdr1 (109/120) and Pvcrt-o (88/120) genes and mutations were found in all geographical regions of South Asia, Southeast Asia and Oceania. The F976:L1076 mutations were more frequent in Oceania (23/37) in comparison to the Southeast Asian (5/10) and South Asian (2/73) regions. A large number of isolates (50/73) from South Asia carried only the L1076 mutation and a few isolates from the Southeast Asia (5/10) and Oceania (8/37) regions. The single F976 mutation was detected only in seven isolates from the South Asian region.

The finding of the F976:L1076 mutations in Oceania is, however, different from earlier studies in PNG between 2006 and 2011; these studies showed the presence of the F976 mutation only [30-32]. This suggests that there was a rise in the number of chloroquine resistance markers since the first reported case of resistant $P$. vivax in the region, even though chloroquine has not been recommended in the antimalarial drug policy since 2009 [33]. In addition, the high prevalence of the $\mathbf{L} 1076$ mutation in the South Asian region was consistent with other recent studies in India and Pakistan with respective mutations of $54.5 \%$ and $98.0 \%$ [34,35]. Only two isolates carried the F976:L1076 mutations in the Indian study [34], whereas the previous study in Pakistan did not find either the F976 mutation or the F976:L1076 mutations [35]. Furthermore, if the hypothesis of a two-step mutation trajectory is true, then the L1076 mutation occurs first, followed by the F976 mutation before the emergence of chloroquine resistance $[17,36,37]$. The finding in the present study with the double F976:L1076 mutations is an indicator that fully developed chloroquine-resistant strains of $P$. vivax are present. A case report of a chloroquine-resistant $P$. vivax infection in a pregnant woman living in Pakistan [38] 
would further support the molecular finding in this study although mutations in the Pvmdr1 gene were not investigated. The increased rate of these mutations suggests that chloroquine resistance in P. vivax will become more common in the South Asia region where chloroquine has remained the first-line drug [39]. Our findings from clinical isolates from Southeast Asia were also similar to other studies in this location $[5-7,16,40]$. A clinical report of chloroquine-resistant $P$. vivax in a Thai pregnant woman indicated that recurrent parasites during Day 21 and 143 carried the double F976:L1076 mutation [40]. This double mutation was found in Thailand in 2008 (49.2\%) and again in 2014 (18.4\%) [7]. The same double mutations were found in 15.4\% of samples in Myanmar between 2009 and 2016 [5]. This could indicate that chloroquine-resistant $P$. vivax is not only present in Thailand but also in neighbouring Myanmar.

Unlike other well-described mutations in the Pvmdr1 gene, the role of the $\mathbf{K} 10$ insertion in Pvcrt-o in chloroquine resistance in $P$. vivax is unclear because this mutation is present in some studies and absent in others [3,5,7,16,34,41]. In Thailand, the K10 insertion was found in 2008 [16], but was not detected again until recently [7,42]. In our study, Indian samples consistently showed the insertion from 2013 to 2017 (see Table S3). In addition to variations in finding the K10 insertion in the Pvcrt-o gene, a recent study suggests that the absence of this mutation (wildtype sequence) in isolates is associated with chloroquine resistance [43]. This would indicate that in our study, the 77 isolates from all three regions which carry the wildtype Pvcrt-o gene are of the chloroquine-resistant genotype.

The findings herein show that the chloroquine-resistant-associated genotypes are present in South Asia, Southeast Asia and Oceania, but chloroquine remains the drug of choice for treatment against P. vivax in India, Pakistan, Thailand and South Korea [21]. Reports of resistant genotypes [38,40,44-46] and the increased mutation frequency found in this study do suggest that resistant phenotypes will continue to emerge in these regions.

A combination of sulfadoxine and pyrimethamine (SP) with other antimalarial drugs is not recommended for treating $P$. vivax [46]. Yet this species of malaria shows emerging mutant genotypes suggesting exposure to SP drug pressures [5,7]. In order to identify SP resistance in P. vivax, mutations in the Pvdhfr and Pvdhps genes were used. These genes are orthologues to Pfdhfr and Pfdhps genes in SP-resistant $P$. falciparum $[5,7,10]$. Furthermore, these gene targets have been correlated with SP resistance in P. vivax [47]. An in vitro study using yeast models which contained the Pvdhfr gene insertion showed that the $\mathrm{IC}_{50}$ value of that yeast expressing the $\mathbf{L} / \mathbf{I} 57: \mathbf{R} 58$ mutations was sevenfold higher than yeast expressing the wildtype gene [48]. Furthermore, genetically modified yeasts containing R58:N117 mutations and those with triple mutations of the Pvdhfr gene were 200-300-fold more resistant to SP than those with the wildtype gene [48]. The L/I57:R58:M61:T117 mutations in the Pvdhfr gene showed a high level of pyrimethamine resistance as the $\overline{\mathrm{I}} \bar{C}_{50}$ value was over 500 -fold in this yeast model [48]. This quadruple mutation was also linked to higher rates of therapeutic failure of SP in a volunteer group of patients than those isolates with wildtype, single, double and triple mutations in their gene sequences [49].

The present study found the $\mathbf{L} / \mathbf{I} 57: \mathbf{R} 58: \mathbf{M} 61: \mathbf{T} 117$ mutations in a large number of isolates from Oceania (21/37), which was followe by the Southeast Asian (4/10) and South Asian (2/73) regions. Our findings were consistent with other studies from these regions [5,7,32,50-52]. An increase in treatment failure by $12 \%$ occurred in P. vivax cases in PNG when the malaria treatment policy in 2000 changed to recommending the use of SP with either chloroquine or amodiaquine as the first-line drug for uncomplicated malaria [53]. India, the largest country in the South Asian region, continues to use SP with other drugs to treat uncomplicated P. falciparum malaria [23]. In the South Asian region, the R58:N117 mutations were present (18/73) in similar numbers found in past studies confirming the higher prevalence of the R58:N117 mutations (28.16\%) than the L/I57:R58:M61:T117 mutations (19.71\%) [51]. It was hypothesised that the $\mathbf{N} 117$ mutation occurs in parasites as an early development towards SP resistance [54]. This is followed by the $\mathbf{R} 58$ mutation, while the other two mutations might occur independently [55]. Therefore, a rise in early stages of SP-resistant mutations indicates ongoing SP drug pressure on P. vivax in the South Asian region. 
Tandem repeat variants were found during the analyses of the Pvdhfr gene in the present study. The predominance of the tandem repeat Type 1 (wildtype sequence) occurs in three regions tested and the presence of low numbers of Type 2 was found in South Asia (9) and Southeast Asia (3). Type 3 variants, which contain four repeat sets of 5'-GGDN-3', were identified in Oceania (19), South Asia (4) and Southeast Asia (1). Other studies have found that all three types are present in India [54,55], whereas Indonesia, Thailand and South Korea have only Type 1 and Type 2 [7,52]. The role of the tandem repeat variants in SP resistance remains unclear $[7,56]$ as these variants are not present in the Pfdhfr gene in P. falciparum [26,57]. However, Type 3 variants were exclusively linked to the L/I57:R58:M61:T117 mutations, which are associated with pyrimethamine resistance in P. vivax. There have been suggestions that these variants are involved in the development of mutations and higher levels of the resistance and therefore may be useful molecular markers [20,51]. Interestingly, 22/24 isolates carrying the Type 3 variant in this study had the L/I57:R58:M61:T117 mutations (see Table S2).

A large number of the studied isolates herein $(103 / \overline{120})$ from all three regions were found to be the wildtype Pvdhps genotype. However, nine isolates from South Asia (6/73), Southeast Asia (2/10) and Oceania (1/37) had the G383:G55 double mutations, which are linked to sulfadoxine resistance in P. vivax $[5,7,58]$. The current results correlate with the findings made in previous studies from these regions $[7,31,32,51,52,55,59]$. Some studies $[47,60]$ showed that the mutations in the Pvdhps gene were more than twice as likely to emerge in isolates with multiple mutations in the Pvdhfr gene. However, only 3/120 of the isolates in the current study were found to carry the $\mathbf{G} 383: \underline{G} 55$ mutations when multiple mutations were present in the Pvdhfr gene (see Table S2).

Gene mutations will be influenced by the different drug policies of each country and these decisions will cause different drug pressures on the parasite genome. The presence of SP-resistant genotypes reflects the use of SP in the past and indicates a misguided use of SP for treating vivax malaria in those countries where SP is currently used. Nevertheless, the findings in our study are limited in scope because samples were collected over a 10-year period and malaria drug policies of each country may have changed during this period. The travel history associated with the clinical samples was not always complete and visits by these patients to multiple endemic countries at the time of infection cannot be excluded. In addition, patients' clinical profiles were not available, and drugs used for treatment could not be determined. Sample numbers from various countries such as Thailand, Solomon Islands, South Korea and Cambodia were not adequately represented.

\section{Materials and Methods}

\subsection{Ethics Statement and Sample Collection}

Clinical blood samples were collected during the time period of 2008-2018 from patients diagnosed with malaria at NSW Health Pathology-ICPMR, Westmead Hospital. At the time of diagnosis, all patients had recently been to malaria-endemic countries, such as India, PNG, Pakistan, Indonesia, Thailand, Solomon Islands, South Korea and Cambodia. There was one patient with no specific country of travel recorded because the patient had travelled to multiple countries within Southeast Asia (SEAN). Plasmodium vivax was diagnosed in these samples by an experienced microscopist and if the microscopic results were unclear, a nested Polymerase Chain Reaction (PCR) was used to determine the malaria species [61]. These clinical blood samples were used with the approval of the human ethics review committee for research in human subjects, research and development office, Western Sydney Local Health District (WSLHD) Research Governance Officer (HREC reference No. LNR/18/WMEAD/139 and SSA reference No. LNRSSA/18/WMEAD/140).

A total of 120 samples with P. vivax infections were included in this study and QIAamp mini DNA extraction kits were used to extract malaria DNA from the blood samples according to the manufacturer's instructions. Extracted DNA was stored at $-20^{\circ} \mathrm{C}$ until required. 
4.2. Sequencing of The Multidrug Resistance 1(Pvmdr1) Gene, The Putative Transporter Protein (Pvcrt-o) Gene, The Dihydrofolate Reductase (Pvdhfr) Gene and The Dihydropteroate Synthetase (Pvdhps) Gene

Specific oligonucleotide primers listed in Table 5 were used to amplify the Pvmdr1 and Pvcrt-o genes by conventional PCR. The total volume of $50 \mu \mathrm{L}$ for the PCR reaction mixture contained $0.2 \mathrm{mM}$ of each dNTP, $1 \mathrm{x}$ of PCR buffer, $1 \mu \mathrm{M}$ of each primer, $2.5 \mathrm{mM}$ of $\mathrm{MgCl}_{2}, 2 \mathrm{U}$ of Taq polymerase and 3-5 $\mu \mathrm{L}$ of extracted sample DNA. Reaction cycle conditions were as follows: $95^{\circ} \mathrm{C}$ for $5 \mathrm{~min}$, then 35 cycles of $\left[94^{\circ} \mathrm{C}\right.$ for $30 \mathrm{~s}, 59^{\circ} \mathrm{C}$ for $45 \mathrm{~s}, 72{ }^{\circ} \mathrm{C}$ for $\left.1.3 \mathrm{~min}\right]$ and the final step was $72{ }^{\circ} \mathrm{C}$ for $7 \mathrm{~min}$.

Table 5. Primers used to amplify the following P. vivax gene targets: the multidrug resistance 1 (Pvmdr1) gene, the putative transporter protein $(P v c r t-o)$ gene, the dihydrofolate reductase (Pvdhfr) gene and the dihydropteroate synthetase (Pvdhps) gene.

\begin{tabular}{|c|c|c|c|c|c|}
\hline Name & Sequences $5^{\prime}-3^{\prime}$ & $\begin{array}{c}\text { Gene } \\
\text { Targets }\end{array}$ & $\begin{array}{l}\text { Product } \\
\text { Size }\end{array}$ & $\begin{array}{l}\text { Tm. } \\
\left({ }^{\circ} \mathrm{C}\right)\end{array}$ & References \\
\hline Pvdhfr (outer) F & CACCGCACCAGTTGATTCCT & \multirow{2}{*}{ Pvdhfr } & \multirow{2}{*}{979} & 67.3 & \multirow{2}{*}{ [25] } \\
\hline Pvdhfr (outer) R & CCTCGGCGTTGTTCTTCT & & & 63.0 & \\
\hline Pvdhfr (nested) F & CСССАССACATAACGAAG & \multirow{2}{*}{ Pvdhfr } & \multirow{2}{*}{755} & 61.5 & \multirow[b]{2}{*}{ [25] } \\
\hline Pvdhfr (nested) R & CCCCACCTTGCTGTAAACC & & & 64.2 & \\
\hline Pvdhps (outer) F & GATGGCGGTTTATTTGTCG & \multirow{2}{*}{ Pvdhps } & \multirow{2}{*}{1009} & 62.8 & \multirow{2}{*}{ [25] } \\
\hline Pvdhps (outer) R & GCTGATCTTTGTCTTGACG & & & 58.5 & \\
\hline Pvdhps (nested) F & GCTGTGGAGAGGATGTTC & \multirow{2}{*}{ Pvdhps } & \multirow{2}{*}{731} & 58.2 & \multirow{2}{*}{ [25] } \\
\hline Pvdhps (nested) R & CCGCTCATCAGTCTGCAC & & & 63.5 & \\
\hline Pvcrt-o F & CAGTGAGAAGCCCCTGTTCG & \multirow{2}{*}{ Pvcrt-o } & \multirow[b]{2}{*}{750} & 67.2 & \multirow[b]{2}{*}{ * } \\
\hline Pvcrt-o R & CCGCTCATCAGTCTGCAC & & & 68.5 & \\
\hline Pvmdr F & GCGAACTCGAATAAGTACTCCСТCTA & \multirow{2}{*}{ Pvmdr1 } & \multirow{2}{*}{762} & 65.4 & \multirow{2}{*}{ [4] } \\
\hline Pvmdr R & GGCGTAGCTTCC CGTAAATAAA & & & 64.8 & \\
\hline
\end{tabular}

* a new primer set was designed by the authors to detect mutations in the resistant marker. (Tm $=$ annealing temperature).

A nested polymerase chain reaction (nested PCR) was used to amplify the Pvdhfr and Pvdhps genes with two pairs of oligonucleotide primers shown in Table 5. The outer PCR reactions were performed in a total volume of $25 \mu \mathrm{L}$ per reaction containing: $0.2 \mathrm{mM}$ of each dNTP, $1 \mathrm{x}$ of PCR buffer, $0.2 \mu \mathrm{M}$ of each primer, $1.75 \mathrm{mM}$ of $\mathrm{MgCl}_{2}$ and $1 \mathrm{U}$ of Taq polymerase. Extracted DNA $(3 \mu \mathrm{L})$ was added to this PCR which was run under the following conditions: $94{ }^{\circ} \mathrm{C}$ for $5 \mathrm{~min}$, then 20 cycles of $\left[94^{\circ} \mathrm{C}\right.$ for $30 \mathrm{~s}, 58^{\circ} \mathrm{C}$ for $30 \mathrm{~s}, 68^{\circ} \mathrm{C}$ for $60 \mathrm{~s}$ ] and final annealing at $68^{\circ} \mathrm{C}$ for $5 \mathrm{~min}$. Products from the outer PCR reaction $(2 \mu \mathrm{L})$ were added into the nested PCR reaction which contained $2 \mathrm{mM}$ of dNTP mix, $1 \mathrm{x}$ of PCR buffer, $0.2 \mu \mathrm{M}$ of each primer, $1.75 \mathrm{mM}$ of $\mathrm{MgCl}_{2}$ and $1 \mathrm{U}$ of Taq polymerase. The following reaction condition was used: $94{ }^{\circ} \mathrm{C}$ for $5 \mathrm{~min}$ followed by 40 cycles of $\left[94^{\circ} \mathrm{C}\right.$ for $30 \mathrm{~s}, 58^{\circ} \mathrm{C}$ for $30 \mathrm{~s}$, $68^{\circ} \mathrm{C}$ for $\left.45 \mathrm{~s}\right]$ with a final step at $68^{\circ} \mathrm{C}$ for $5 \mathrm{~min}$. All amplicons were analysed by electrophoresis on a $1.5 \%$ agarose gel.

The amplicons of Pvmdr1, Pvcrt-o, Pvdhfr and Pvdhps were sequenced by Macrogen in South Korea. All DNA sequences were assembled using the Sequencher 5.3 program. The assembled DNA sequences were aligned and translated to amino acid sequences using the MEGA 7 program and compared to Genbank reference strains (Reference No. Pvdhfr: XM001615032 [62] and X98123.1 [27], Pvdhps: XM001617159 [62], Pvcrt-o: AF314649 [12] and Pvmdr: AY618622 [18]) in order to identify the presence of amino acid changes in the expected protein. All nonsynonymous mutations in the targeted genes identified in this study are shown in Tables 6 and 7. 
Table 6. Nonsynonymous mutations associated with chloroquine resistance in a multidrug resistance 1 (Pvmdr1) gene and a putative transporter protein (Pvcrt-o) gene.

\begin{tabular}{|c|c|c|c|c|}
\hline Genes & $\begin{array}{l}\text { Nucleotide } \\
\text { Position }\end{array}$ & $\begin{array}{l}\text { Nucleotide } \\
\text { Change }\end{array}$ & $\begin{array}{l}\text { Amino Acid } \\
\text { Position }\end{array}$ & Amino Acid Change \\
\hline \multirow{2}{*}{ Pvmdr1 } & 2928-2930 & $\begin{array}{l}\text { TAC }->\text { TTC } \\
(\text { g. } 2929 A>\text { T) }\end{array}$ & 976 & $\begin{array}{c}\text { (Y) Tyrosine }->(\mathbf{F}) \text { Phenylalanine } \\
(\text { Y } 976 \mathbf{F})\end{array}$ \\
\hline & $3228-3230$ & $\begin{array}{l}\text { TTT }->\text { CTT } \\
(\text { g.3228T }>\text { C) }\end{array}$ & 1076 & $\begin{array}{c}\text { (F) Phenylalanine }->(\underline{\mathbf{L}}) \text { Leucine } \\
(\mathrm{F} 1076 \underline{\mathbf{L}})\end{array}$ \\
\hline Pvcrt-o & 30 & $\begin{array}{c}\text { AAG } \\
\text { (g.30_31insAAG) }\end{array}$ & 10 & $\begin{array}{l}\text { () Lysine (Insertion) } \\
\text { (ㅌ10 insertion) }\end{array}$ \\
\hline
\end{tabular}

Pvmdr1 = the multidrug resistance 1 gene; Pvcrt- $o$ = the putative transporter protein gene.

Table 7. Nonsynonymous mutations associated with sulphadoxine resistance in dihydrofolate reductase (Pvdhfr) gene and nonsynonymous mutations associated with pyrimethamine resistance in dihydropteroate synthetase (Pvdhps) gene.

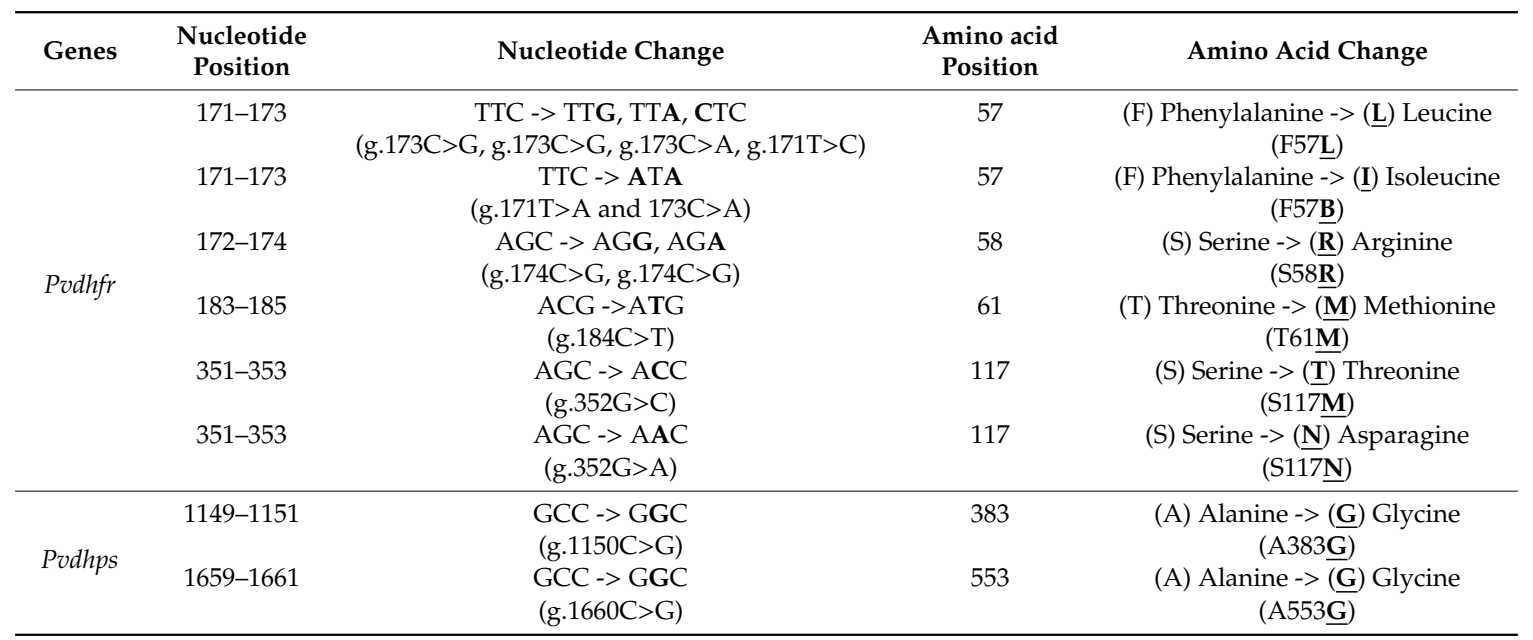

Pvdhfr = the dihydrofolate reductase gene; Pvdhps = the dihydropteroate synthetase gene.

\section{Conclusions}

High prevalence of chloroquine-resistance-associated genotypes highlights the severe situation of chloroquine resistance in P. vivax in Oceania and South Asian and Southeast Asian regions. Genetic monitoring for-drug resistant $P$. vivax in travellers returning to Australia allows pre-empting rising treatment failures in these endemic countries. Furthermore, this data will serve as an early warning for imported cases of chloroquine-resistant strains of $P$. vivax so that alternative drug therapies can be instigated. The finding of mutations in Pvdhfr and Pvdhps genes suggests that SP drug pressure on $P$. vivax is already present, even though this drug is not recommended for use against $P$. vivax in these regions.

Supplementary Materials: The following are available online at http://www.mdpi.com/2076-0817/9/2/101/s1, Table S1: The number of successful sequences obtained from 120 clinical samples, Table S2: Total of targeted sequences obtained from clinical samples, Table S3: The table of mutations in four genes found in Indian samples between 2008 and 2018, Table S4: The table of orthologous genes associated with drug resistance between $P$. falciparum and P. vivax.

Author Contributions: Conceptualization, C.N.; Funding acquisition, W.M. and R.L.; Investigation, C.N.; Methodology, C.N.; Resources, W.M., N.S. and R.L.; Supervision, W.M., N.S. and R.L.; Validation, C.N., W.M., N.S. and R.L.; Writing—original draft, C.N.; Writing—review \& editing, W.M., N.S., J.E. and R.L. All authors have read and agreed to the published version of the manuscript. 
Funding: This research was funded by a SSEAC Collaborative Research Grant, grant number RY668 to R.L. and W.M.

Acknowledgments: We would like to thank our colleagues at the Westmead Institute for Medical Research for their laboratory and academic support.

Conflicts of Interest: The authors declare no conflict of interest.

Ethical Statement: This research was approved by the human ethical review committee for research in human subjects, research and development office, Western Sydney Local Health District (WSLHD) Research Governance Officer (HREC reference No. LNR/18/WMEAD/139 and SSA reference No. LNRSSA/18/WMEAD/140).

\section{References}

1. Knope, K.E.; Muller, M.; Kurucz, N.; Doggett, S.L.; Feldman, R.; Johansen, C.A.; Hobby, M. 2013-2014: Annual Report of the National Arbovirus and Malaria Advisory Committee. Commun. Dis. Intell. 2016, 40, E401-E436.

2. Tatem, A.J.; Jia, P.; Ordanovich, D.; Falkner, M.; Huang, Z.; Howes, R.; Hay, S.I.; Gething, P.W.; Smith, D.L. The geography of imported malaria to non-endemic countries: A meta-analysis of nationally reported statistics. Lancet Infect. Dis. 2017, 17, 98-107. [CrossRef]

3. Lu, F.; Lim, C.S.; Nam, D.-H.; Kim, K.; Lin, K.; Kim, T.-S.; Lee, H.-W.; Chen, J.-H.; Wang, Y.; Sattabongkot, J. Genetic polymorphism in pvmdr1 and pvcrt-o genes in relation to in vitro drug susceptibility of Plasmodium vivax isolates from malaria-endemic countries. Acta Trop. 2011, 117, 69-75. [CrossRef]

4. Mint Lekweiry, K.; Ould Mohamed Salem Boukhary, A.; Gaillard, T.; Wurtz, N.; Bogreau, H.; Hafid, J.E.; Trape, J.-F.; Bouchiba, H.; Ould Ahmedou Salem, M.S.; Pradines, B. Molecular surveillance of drug-resistant Plasmodium vivax using pvdhfr, pvdhps and pvmdr1 markers in Nouakchott, Mauritania. J. Antimicrob. Chemother. 2011, 67, 367-374. [CrossRef]

5. Nyunt, M.H.; Han, J.-H.; Wang, B.; Aye, K.M.; Aye, K.H.; Lee, S.-K.; Htut, Y.; Kyaw, M.P.; Han, K.T.; Han, E.-T. Clinical and molecular surveillance of drug resistant vivax malaria in Myanmar (2009-2016). Malar. J. 2017, 16, 117. [CrossRef]

6. Rungsihirunrat, K.; Muhamad, P.; Chaijaroenkul, W.; Kuesap, J.; Na-Bangchang, K. Plasmodium vivax drug resistance genes; Pvmdr1 and Pvcrt-o polymorphisms in relation to chloroquine sensitivity from a malaria endemic area of Thailand. Korean J. Parasitol. 2015, 53, 43. [CrossRef]

7. Tantiamornkul, K.; Pumpaibool, T.; Piriyapongsa, J.; Culleton, R.; Lek-Uthai, U. The prevalence of molecular markers of drug resistance in Plasmodium vivax from the border regions of Thailand in 2008 and 2014. Int. J. Parasitol. Drugs Drug Resist. 2018, 8, 229-237. [CrossRef]

8. Rieckmann, K.; Davis, D.; Hutton, D. Plasmodium vivax resistance to chloroquine? Lancet 1989, 334, 1183-1184. [CrossRef]

9. Lu, F.; Wang, B.; Cao, J.; Sattabongkot, J.; Zhou, H.; Zhu, G.; Kim, K.; Gao, Q.; Han, E.-T. Prevalence of drug resistance-associated gene mutations in Plasmodium vivax in Central China. Korean J. Parasitol. 2012, 50, 379. [CrossRef]

10. Price, R.N.; Auburn, S.; Marfurt, J.; Cheng, Q. Phenotypic and genotypic characterisation of drug-resistant Plasmodium vivax. Trends Parasitol. 2012, 28, 522-529. [CrossRef]

11. Parija, S.; Praharaj, I. Drug resistance in malaria. Indian J. Med. Microbiol. 2011, 29, 243. [CrossRef]

12. Nomura, T.; Carlton, J.M.; Baird, J.K.; Del Portillo, H.A.; Fryauff, D.J.; Rathore, D.; Fidock, D.A.; Su, X.-Z.; Collins, W.E.; McCutchan, T.F. Evidence for different mechanisms of chloroquine resistance in 2 Plasmodium species that cause human malaria. J. Infect. Dis. 2001, 183, 1653-1661. [CrossRef]

13. Wirjanata, G.; Handayuni, I.; Prayoga, P.; Leonardo, L.; Apriyanti, D.; Trianty, L.; Wandosa, R.; Gobay, B.; Kenangalem, E.; Poespoprodjo, J.R. Plasmodium falciparum and Plasmodium vivax demonstrate contrasting chloroquine resistance reversal phenotypes. Antimicrob. Agents Chemother. 2017, 61, e00355-17. [CrossRef]

14. World Health Organization. Control and Elimination of Plasmodium Vivax Malaria: A Technical Brief; World Health Organization: Geneva, Switzerland, 2015.

15. World Health Organization. Global Report on Antimalarial Drug Efficacy and Drug Resistance; World Health Organization: Geneva, Switzerland, 2010. 
16. Suwanarusk, R.; Russell, B.; Chavchich, M.; Chalfein, F.; Kenangalem, E.; Kosaisavee, V.; Prasetyorini, B.; Piera, K.A.; Barends, M.; Brockman, A. Chloroquine resistant Plasmodium vivax: In vitro characterisation and association with molecular polymorphisms. PLoS ONE 2007, 2, e1089. [CrossRef]

17. Suwanarusk, R.; Chavchich, M.; Russell, B.; Jaidee, A.; Chalfein, F.; Barends, M.; Prasetyorini, B.; Kenangalem, E.; Piera, K.; Lek-Uthai, U. Amplification of pvmdr1 associated with multidrug-resistant Plasmodium vivax. J. Infect. Dis. 2008, 198, 1558-1564. [CrossRef]

18. Brega, S.; Meslin, B.; De Monbrison, F.; Severini, C.; Gradoni, L.; Udomsangpetch, R.; Sutanto, I.; Peyron, F.; Picot, S. Identification of the Plasmodium vivax mdr-like gene (pvmdr1) and analysis of single-nucleotide polymorphisms among isolates from different areas of endemicity. J. Infect. Dis. 2005, 191, 272-277. [CrossRef]

19. Ganguly, S.; Saha, P.; Guha, S.K.; Das, S.; Bera, D.K.; Biswas, A.; Kundu, P.K.; Saha, B.; Ray, K.; Maji, A.K. In vivo therapeutic efficacy of chloroquine alone or in combination with primaquine against vivax malaria in Kolkata, West Bengal, India, and polymorphism in pvmdr1 and pvcrt-o genes. Antimicrob. Agents Chemother. 2013, 57, 1246-1251. [CrossRef]

20. Imwong, M.; Pukrittayakamee, S.; Rénia, L.; Letourneur, F.; Charlieu, J.-P.; Leartsakulpanich, U.; Looareesuwan, S.; White, N.J.; Snounou, G. Novel point mutations in the dihydrofolate reductase gene of Plasmodium vivax: Evidence for sequential selection by drug pressure. Antimicrob. Agents Chemother. 2003, 47, 1514-1521. [CrossRef]

21. World Health Organization. World Malaria Report 2019; World Health Organization: Geneva, Switzerland, 2019.

22. Leslie, T.; Mayan, M.I.; Hasan, M.A.; Safi, M.H.; Klinkenberg, E.; Whitty, C.J.; Rowland, M. Sulfadoxinepyrimethamine, chlorproguanil-dapsone, or chloroquine for the treatment of Plasmodium vivax malaria in Afghanistan and Pakistan: A randomized controlled trial. JAMA 2007, 297, 2201-2209. [CrossRef]

23. Rungsihirunrat, K.; Sibley, C.H.; Mungthin, M.; Na-Bangchang, K. Geographical distribution of amino acid mutations in Plasmodium vivax DHFR and DHPS from malaria endemic areas of Thailand. Am. J. Trop. Med. Hyg. 2008, 78, 462-467. [CrossRef]

24. Auliff, A.; Sibley, C.H.; Mungthin, M.; Na-Bangchang, K. Amino acid mutations in Plasmodium vivax DHFR and DHPS from several geographical regions and susceptibility to antifolate drugs. Am. J. Trop. Med. Hyg. 2006, 75, 617-621. [CrossRef]

25. Ding, S.; Ye, R.; Zhang, D.; Sun, X.; Zhou, H.; McCutchan, T.F.; Pan, W. Anti-folate combination therapies and their effect on the development of drug resistance in Plasmodium vivax. Sci. Rep. 2013, 3, 1008. [CrossRef]

26. Lu, F.; Lim, C.S.; Nam, D.H.; Kim, K.; Lin, K.; Kim, T.-S.; Lee, H.-W.; Chen, J.-H.; Wang, Y.; Sattabongkot, J. Mutations in the antifolate-resistance-associated genes dihydrofolate reductase and dihydropteroate synthase in Plasmodium vivax isolates from malaria-endemic countries. Am. J. Trop. Med. Hyg. 2010, 83, 474-479. [CrossRef]

27. de Pécoulas, P.E.; Basco, L.K.; Tahar, R.; Ouatas, T.; Mazabraud, A. Analysis of the Plasmodium vivax dihydrofolate reductase-thymidylate synthase gene sequence. Gene 1998, 211, 177-185. [CrossRef]

28. Russell, B.M.; Udomsangpetch, R.; Rieckmann, K.H.; Kotecka, B.M.; Coleman, R.E.; Sattabongkot, J. Simple in vitro assay for determining the sensitivity of Plasmodium vivax isolates from fresh human blood to antimalarials in areas where vivax is endemic. Antimicrob. Agents Chemother. 2003, 47, 170-173. [CrossRef]

29. Singh, G.; Singh, R.; Urhehar, A.D. Simple molecular methods for early detection of chloroquine drug resistance in Plasmodium vivax and Plasmodium falciparum. J. Clin. Diagn. Res. JCDR 2016, 10, DC19. [CrossRef]

30. Marfurt, J.; de Monbrison, F.; Brega, S.; Barbollat, L.; Müller, I.; Sie, A.; Goroti, M.; Reeder, J.C.; Beck, H.-P.; Picot, S. Molecular markers of in vivo Plasmodium vivax resistance to amodiaquine plus sulfadoxine-pyrimethamine: Mutations in pvdhfr and pvmdr1. J. Infect. Dis. 2008, 198, 409-417. [CrossRef]

31. Barnadas, C.; Kent, D.; Timinao, L.; Iga, J.; Gray, L.R.; Siba, P.; Mueller, I.; Thomas, P.J.; Zimmerman, P.A. A new high-throughput method for simultaneous detection of drug resistance associated mutations in Plasmodium vivax dhfr, dhps and mdr1 genes. Malar. J. 2011, 10, 282. [CrossRef]

32. Barnadas, C.; Timinao, L.; Javati, S.; Iga, J.; Malau, E.; Koepfli, C.; Robinson, L.J.; Senn, N.; Kiniboro, B.; Rare, L. Significant geographical differences in prevalence of mutations associated with Plasmodium falciparum and Plasmodium vivax drug resistance in two regions from Papua New Guinea. Malar. J. 2015, 14, 399. [CrossRef] 
33. Chuang, I.; Richie, T.L. World Malaria Report 2010: Documenting progress towards malaria eradication. Expert Rev. Vaccines 2012, 11, 39-41. [CrossRef]

34. Joy, S.; Mukhi, B.; Ghosh, S.K.; Achur, R.N.; Gowda, D.C.; Surolia, N. Drug resistance genes: Pvcrt-o and pvmdr-1 polymorphism in patients from malaria endemic South Western Coastal Region of India. Malar. J. 2018, 17, 40. [CrossRef]

35. Khattak, A.A.; Venkatesan, M.; Khatoon, L.; Ouattara, A.; Kenefic, L.J.; Nadeem, M.F.; Nighat, F.; Malik, S.A.; Plowe, C.V. Prevalence and patterns of antifolate and chloroquine drug resistance markers in Plasmodium vivax across Pakistan. Malar. J. 2013, 12, 310. [CrossRef]

36. Orjuela-Sánchez, P.; de Santana Filho, F.S.; Machado-Lima, A.; Chehuan, Y.F.; Costa, M.R.F.; Alecrim, M.d.G.C.; del Portillo, H.A. Analysis of single-nucleotide polymorphisms in the crt-o and mdr1 genes of Plasmodium vivax among chloroquine-resistant isolates from the Brazilian Amazon region. Antimicrob. Agents Chemother. 2009, 53, 3561-3564. [CrossRef]

37. Imwong, M.; Pukrittayakamee, S.; Pongtavornpinyo, W.; Nakeesathit, S.; Nair, S.; Newton, P.; Nosten, F.; Anderson, T.J.; Dondorp, A. Gene amplification of the multidrug resistance 1 gene of Plasmodium vivax isolates from Thailand, Laos, and Myanmar. Antimicrob. Agents Chemother. 2008, 52, 2657-2659. [CrossRef]

38. Waheed, A.A.; Ghanchi, N.K.; Rehman, K.A.; Raza, A.; Mahmood, S.F.; Beg, M.A. Vivax malaria and chloroquine resistance: A neglected disease as an emerging threat. Malar. J. 2015, 14, 146. [CrossRef]

39. World Health Organization. World Malaria Report 2018; World Health Organization: Geneva, Switzerland, 2018.

40. Rijken, M.J.; Boel, M.E.; Russell, B.; Imwong, M.; Leimanis, M.L.; Phyo, A.P.; Muehlenbachs, A.; Lindegardh, N.; McGready, R.; Rénia, L. Chloroquine resistant vivax malaria in a pregnant woman on the western border of Thailand. Malar. J. 2011, 10, 113. [CrossRef]

41. Anantabotla, V.; Antony, H.A.; Parija, S.C.; Rajkumari, N.; Kini, J.R.; Manipura, R.; Nag, V.L.; Gadepalli, R.; Chayani, N.; Patro, S. Polymorphisms in genes associated with drug resistance of Plasmodium vivax in India. Parasitol. Int. 2019, 70, 92-97. [CrossRef]

42. Noisang, C.; Prosser, C.; Meyer, W.; Chemoh, W.; Ellis, J.; Sawangjaroen, N.; Lee, R. Molecular detection of drug resistant malaria in Southern Thailand. Malar. J. 2019, 18, 275. [CrossRef]

43. Sá, J.M.; Kaslow, S.R.; Barros, R.R.M.; Brazeau, N.F.; Parobek, C.M.; Tao, D.; Salzman, R.E.; Gibson, T.J.; Velmurugan, S.; Krause, M.A. Plasmodium vivax chloroquine resistance links to pvcrt transcription in a genetic cross. Nat. Commun. 2019, 10, 4300. [CrossRef]

44. Garg, M.; Gopinathan, N.; Bodhe, P.; Kshirsagar, N. Vivax malaria resistant to chloroquine: Case reports from Bombay. Trans. R. Soc. Trop. Med. Hyg. 1995, 89, 656-657. [CrossRef]

45. Golassa, L.; Erko, B.; Baliraine, F.N.; Aseffa, A.; Swedberg, G. Polymorphisms in chloroquine resistance-associated genes in Plasmodium vivax in Ethiopia. Malar. J. 2015, 14, 164. [CrossRef] [PubMed]

46. World Health Organization. Guidelines for the Treatment of Malaria; World Health Organization: Geneva, Switzerland, 2015.

47. Hawkins, V.N.; Joshi, H.; Rungsihirunrat, K.; Na-Bangchang, K.; Sibley, C.H. Antifolates can have a role in the treatment of Plasmodium vivax. Trends Parasitol. 2007, 23, 213-222. [CrossRef] [PubMed]

48. Hastings, M.D.; Maguire, J.D.; Bangs, M.J.; Zimmerman, P.A.; Reeder, J.C.; Baird, J.K.; Sibley, C.H. Novel Plasmodium vivax dhfr alleles from the Indonesian Archipelago and Papua New Guinea: Association with pyrimethamine resistance determined by a Saccharomyces cerevisiae expression system. Antimicrob. Agents Chemother. 2005, 49, 733-740. [CrossRef]

49. Hastings, M.D.; Porter, K.M.; Maguire, J.D.; Susanti, I.; Kania, W.; Bangs, M.J.; Sibley, C.H.; Baird, J.K. Dihydrofolate reductase mutations in Plasmodium vivax from Indonesia and therapeutic response to sulfadoxine plus pyrimethamine. J. Infect. Dis. 2004, 189, 744-750. [CrossRef]

50. Barnadas, C.; Koepfli, C.; Karunajeewa, H.A.; Siba, P.M.; Davis, T.M.; Mueller, I. Characterization of treatment failure in efficacy trials of drugs against Plasmodium vivax by genotyping neutral and drug resistance-associated markers. Antimicrob. Agents Chemother. 2011, 55, 4479-4481. [CrossRef]

51. Prajapati, S.K.; Joshi, H.; Dev, V.; Dua, V.K. Molecular epidemiology of Plasmodium vivax anti-folate resistance in India. Malar. J. 2011, 10, 102. [CrossRef]

52. Asih, P.B.; Marantina, S.S.; Nababan, R.; Lobo, N.F.; Rozi, I.E.; Sumarto, W.; Dewi, R.M.; Tuti, S.; Taufik, A.S.; Sauerwein, R.W. Distribution of Plasmodium vivax pvdhfr and pvdhps alleles and their association with sulfadoxine-pyrimethamine treatment outcomes in Indonesia. Malar. J. 2015, 14, 365. [CrossRef] 
53. Marfurt, J.; Müeller, I.; Sie, A.; Maku, P.; Goroti, M.; Reeder, J.C.; Beck, H.-P.; Genton, B. Low efficacy of amodiaquine or chloroquine plus sulfadoxine-pyrimethamine against Plasmodium falciparum and vivax malaria in Papua New Guinea. Am. J. Trop. Med. Hyg. 2007, 77, 947-954. [CrossRef]

54. Brega, S.; De Monbrison, F.; Severini, C.; Udomsangpetch, R.; Sutanto, I.; Ruckert, P.; Peyron, F.; Picot, S. Real-time PCR for dihydrofolate reductase gene single-nucleotide polymorphisms in Plasmodium vivax isolates. Antimicrob. Agents Chemother. 2004, 48, 2581-2587. [CrossRef]

55. Das, S.; Banik, A.; Hati, A.K.; Roy, S. Low prevalence of dihydro folate reductase (dhfr) and dihydropteroate synthase (dhps) quadruple and quintuple mutant alleles associated with SP resistance in Plasmodium vivax isolates of West Bengal, India. Malar. J. 2016, 15, 395. [CrossRef]

56. Yaqoob, A.; Khattak, A.A.; Nadeem, M.F.; Fatima, H.; Mbambo, G.; Ouattara, A.; Adams, M.; Zeeshan, N.; Takala-Harrison, S. Prevalence of molecular markers of sulfadoxine-pyrimethamine and artemisinin resistance in Plasmodium falciparum from Pakistan. Malar. J. 2018, 17, 471. [CrossRef] [PubMed]

57. de Pécoulas, P.E.; Tahar, R.; Ouatas, T.; Mazabraud, A.; Basco, L.K. Sequence variations in the Plasmodium vivax dihydrofolate reductase-thymidylate synthase gene and their relationship with pyrimethamine resistance. Mol. Biochem. Parasitol. 1998, 92, 265-273. [CrossRef]

58. Huang, B.; Huang, S.; Su, X.-Z.; Tong, X.; Yan, J.; Li, H.; Lu, F. Molecular surveillance of pvdhfr, pvdhps, and pvmdr-1 mutations in Plasmodium vivax isolates from Yunnan and Anhui provinces of China. Malar. J. 2014, 13, 346. [CrossRef] [PubMed]

59. Gresty, K.J.; Gray, K.-A.; Bobogare, A.; Wini, L.; Taleo, G.; Hii, J.; Cheng, Q.; Waters, N.C. Genetic mutations in Plasmodium falciparum and Plasmodium vivax dihydrofolate reductase (DHFR) and dihydropteroate synthase (DHPS) in Vanuatu and Solomon Islands prior to the introduction of artemisinin combination therapy. Malar. J. 2014, 13, 402. [CrossRef] [PubMed]

60. Imwong, M.; Pukrittayakamee, S.; Cheng, Q.; Moore, C.; Looareesuwan, S.; Snounou, G.; White, N.J.; Day, N.P. Limited polymorphism in the dihydropteroate synthetase gene (dhps) of Plasmodium vivax isolates from Thailand. Antimicrob. Agents Chemother. 2005, 49, 4393-4395. [CrossRef] [PubMed]

61. Snounou, G.; Viriyakosol, S.; Jarra, W.; Thaithong, S.; Brown, K.N. Identification of the four human malaria parasite species in field samples by the polymerase chain reaction and detection of a high prevalence of mixed infections. Mol. Biochem. Parasitol. 1993, 58, 283-292. [CrossRef]

62. Carlton, J.M.; Adams, J.H.; Silva, J.C.; Bidwell, S.L.; Lorenzi, H.; Caler, E.; Crabtree, J.; Angiuoli, S.V.; Merino, E.F.; Amedeo, P. Comparative genomics of the neglected human malaria parasite Plasmodium vivax. Nature 2008, 455, 757-763. [CrossRef] 